\title{
Effect of tree age on chemical compounds of ancient Anatolian black pine (Pinus nigra subsp. pallasiana) needles in Northwest Turkey
}

\author{
Nezahat Turfan ${ }^{(1)}$, \\ Mehtap Alay ${ }^{(1)}$, \\ Temel Sariyildiz ${ }^{(2)}$
}

\begin{abstract}
Plant primary and secondary metabolites are chemical compounds synthesized for essential functions, such as growth and development (primary metabolites), and specific functions, such as pollinator attraction or defense against herbivory (secondary metabolites). Their concentrations in plants are genetically determined, but are also affected by environmental factors. Among these factors, plant age has been reported to influence plant chemical compounds under similar environmental conditions. We aimed to investigate the chemical compounds of ancient Anatolian black pine (Pinus nigra subsp. pallasiana) needles from trees of different ages. Needles of over 500-, 200-, 100-, 50-, and 25-year-old black pine trees growing under similar environmental conditions were sampled and analyzed for photosynthetic pigments (chlorophyll $a$, chlorophyll $b$ and carotenoids), proline, total soluble protein, glucose, sucrose, total soluble sugar, peroxidation level (MDA-malondialdehyde), hydrogen peroxide $\left(\mathrm{H}_{2} \mathrm{O}_{2}\right)$ and antioxidants such as ascorbate peroxidase (APX), catalase (CAT) and superoxide dismutase (SOD) activities. Significant differences for chemical composition associated with age were found. In general, results showed that over 500-year-old Anatolian black pine had the highest proline, total soluble protein, $\mathrm{H}_{2} \mathrm{O}_{2}$, sucrose, total soluble carbohydrates, APX, CAT and SOD concentrations, whereas they had the lowest chlorophyll $a$, total chlorophyll, total carotenoid and glucose concentrations. However, 200-year-old trees had the highest glucose, but the lowest chlorophyll $b$, proline, $\mathrm{H}_{2} \mathrm{O}_{2}$ and total soluble carbohydrates. 50- and 25-year-old trees together showed the highest chlorophyll $a$ and $b$, total chlorophyll, total carotenoid and MDA, but lowest total soluble protein and sucrose. In conclusion, these results provide valuable insight into the chemical composition of Anatolian black pine needles in relation to their age, and can be used for complementing studies on tree growth-defence relationships.
\end{abstract}

Keywords: Ancient Trees, Anatolian Black Pine, Chemical Composition, Turkey velopment in trees occur under the joint influence of environmental conditions and anthropic impacts (Koch et al. 2004, Peichl \& Arain 2006).

Tree growth accelerates as canopies develop in young forests and declines substantially soon after the maximum leaf area is attained. The causes of this decline are multiple and may be linked to ageand/or size-related processes. Three stages can be identified in the growth of trees over time. During the formation phase (i.e.,
(1) Kastamonu University, Faculty of Science and Art, Department of Biology, 37100 Kastamonu (Turkey); (2) Bursa Technical University, Faculty of Forestry, Department of Forest Engineering, 16310 Bursa (Turkey)

@ Temel Sariyildiz (temel.sariyildiz@btu.edu.tr)

Received: Oct 25, 2017 - Accepted: Jan 30, 2018

Citation: Turfan N, Alay M, Sariyildiz T (2018). Effect of tree age on chemical compounds of ancient Anatolian black pine (Pinus nigra subsp. pallasiana) needles in Northwest Turkey. iForest 11: 406-410. - doi: 10.3832/ifor2665-011 [online 2018-05-15]

Communicated by: Silvano Fares before canopy closure) high-rate metabolic synthesis leads to a rapid growth, which is due to the continuous growth and division of meristematic cells, and requires significant amounts of energy (Köstner et al. 2002). In the second phase (maturity), leaf metabolic activity continues but wood anatomy and chemistry start to change, and cambial activity slow downs (Greenwood et al. 2010). In the last phase, leaf area and production are reduced, while branch losses are accelerated, plant injuries are more frequent, as well as attack of pathogens or pests (Gower et al. 1996, Sariyildiz \& Anderson 2006).

Anatolian black pine (Pinus nigra subsp. pallasiana) is the second most widely distributed forest tree species in Turkey. The species covers, either as pure or mixed stands, approximately 4.2 million ha of $\mathbf{2 1 . 2}$ million ha total forest land in Turkey. Climatically, it grows in transitional regions between maritime and continental climates, extending as far as the inner Anatolian steppe (Atalay \& Efe 2012). Due to its economic importance in Turkey, the ecology and silviculture of Anatolian black pine have been extensively studied. Neverthe- 


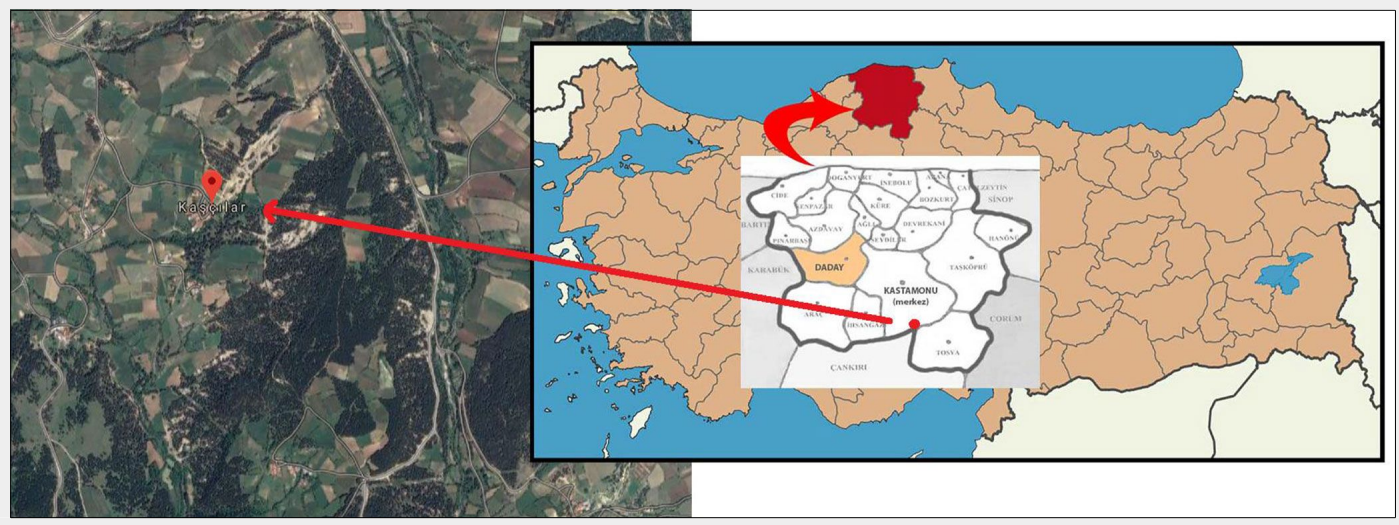

Fig. 1 - Location of the study area (near the Kasçilar village, Kastamonu province, Northern Turkey).

less, no studies have investigated how stand characteristics and tree age influence the chemical composition of Anatolian black pine needles. The chemical composition of plant litter is indicative of its quality as a resource for decomposer organisms. Litter quality has been shown to be a major determinant of litter decomposition rates both within and across terrestrial ecosystems. To better understand litter decomposition dynamics, nutrient cycling, soil organic matter dynamics, and $\mathrm{C}$ storage and release in Anatolian black pine forests, factors influencing foliage and litter chemistry of Anatolian black pine needles warrant deep investigation.

We aimed at investigating the chemical composition of Anatolian black pine needles of different ages. Needles of $>500-$, 200-, 100-, 50-, and 25-year-old black pine trees growing under similar environmental conditions were sampled and analyzed for their contents in photosynthetic pigments, proline, soluble proteins, amino acids, glucose, sucrose, soluble sugar, as well as levels of peroxidation (MDA-malondialdehyde), $\mathrm{H}_{2} \mathrm{O}_{2}$ and antioxidants (ascorbate peroxidase, APX, catalase, CAT, and superoxide dismutase, SOD).

\section{Materials and methods}

\section{Study area and tree sampling}

This study was carried out near the Kasçilar village, $18 \mathrm{~km}$ from Kastamonu province, Northwest Turkey $\left(41^{\circ} 11^{\prime} 38^{\prime \prime} \mathrm{N}, 33^{\circ}\right.$ 53' 07" E, elevation 1350 m a.s.l., NW aspect - Fig. 1). The climate in the area is continental, with long, cold and snowy winters and short and warm summers. The seasonal and daily temperatures show extreme values and precipitation is generally low (Duran 2017). Meteorological data over the period 1975-2016 (Kastamonu Meteorological Station, $800 \mathrm{~m}$ a.s.l.) indicate that average annual precipitation is $490 \mathrm{~mm}$, while average monthly temperatures range from -0.8 ${ }^{\circ} \mathrm{C}$ in January to $20.2{ }^{\circ} \mathrm{C}$ in July.

Pure Anatolian black forest stands of different age classes grow on a fertile and deep soil. The humus type is moder with moderate litter decomposition rates. The selected Anatolian black pine trees varied in age from 25 to over 500 years and were clearly grouped into five age classes (Tab. 1). All tree age classes were examined within $400 \mathrm{~m}^{2}(20 \times 20 \mathrm{~m})$ plot. Canopy cover was rather open for older pine trees over 500-year old (about 0.5) and closer for younger pine trees (about 0.7-0.8). Measurements of diameter at breast height (DBH) and height were made on three sample trees for each tree class in summer 2017. DBH was measured using a diameter tape. Tree age was determined by dendrochronological approach, coring trees at breast height. Tree heights were measured with a Blume-Leiss clinometer.

Fresh needles from the lower parts of the three sample trees for each age class were collected and placed in bags. These samples were then combined to form a mixed sample for each age class and analyzed for photosynthetic pigment amounts (chlorophyll $a$, chlorophyll $b$ and carotenoids), proline, protein, lipid peroxidation and hydrogen peroxide $\left(\mathrm{H}_{2} \mathrm{O}_{2}\right)$, glucose, sucrose and total soluble carbohydrates, and ascorbate peroxidase, catalase, and superoxide dismutase enzyme activities.

Tab. 1 - Mean characteristics of Anatolian black pine (Pinus nigra) donor trees used in this study. Mean attributes are shown for each tree age class. DBH is diameter at breast height.

\begin{tabular}{ccccc}
\hline Class & $\begin{array}{c}\text { No. of } \\
\text { Trees }\end{array}$ & $\begin{array}{c}\text { Age at } \mathbf{1 . 3} \mathbf{~ m} \\
\text { (year) }\end{array}$ & $\begin{array}{c}\text { DBH } \\
(\mathbf{c m})\end{array}$ & $\begin{array}{c}\text { Height } \\
(\mathbf{m})\end{array}$ \\
\hline 1 & 3 & over 500 & 320 & 28 \\
2 & 3 & 200 & 234 & 27 \\
3 & 3 & 100 & 157 & 32 \\
4 & 3 & 50 & 78 & 25 \\
5 & 3 & 25 & 34 & 21 \\
\hline
\end{tabular}

\section{Chemical analyses of needle samples}

For the analysis of photosynthetic pigments, $500 \mathrm{mg}$ of leaf samples were homogenized with $10 \mathrm{ml}$ of $80 \%$ acetone and centrifuged at $3000 \mathrm{rpm}$ for 15 minutes. The extract was utilized for chlorophyll estimation (Arnon 1949). Carotenoid amount was estimated using the Jaspars' formula according to the method of Witham et al. (1971). Proline content was determined according to the modified method of Bates et al. (1973). Total soluble protein contents were analyzed according to the method of Bradford (1976) using the Bio-Rad ${ }^{\oplus}$ assay kit with bovine serum albumin as a calibration standard. The level of lipid peroxidation products was determined using the thiobarbituric method and expressed as nmol of MDA-malondialdehyde formed using an extinction coefficient of $155 \mathrm{mM}^{-1}$ $\mathrm{cm}^{-1}$ as $\mu \mathrm{mol}$ MDA-malondialdehyde, according to Lutts et al. (1996). Hydrogen peroxide was determined following Velikova et al. (2000). Soluble sugars were assayed according to Pearson's method (Pearson et al. 1976). Antioxidants were determined by using dry needle samples $(500 \mathrm{mg})$, which were ground in powder using liquid nitrogen. The powder was homogenized in $5 \mathrm{~mL}$ phosphate potassium (pH 7.6) with $0.1 \mathrm{mM}$ of EDTA. The homogenate was then centrifuged to $15,000 \times \mathrm{g}$ for $20 \mathrm{~min}$ at $4{ }^{\circ} \mathrm{C}$. The supernatant was kept, and $0.8 \mathrm{ml}$ phosphate potassium 0.2 $M$ was added. The homogenate was centrifuged again to $15,000 \times g$ for $15 \mathrm{~min}$. The combined supernatants were stored on ice and used in order to determine the activity of detoxifying enzymes. The activity of SOD was assayed by measuring its ability to inhibit the photochemical reduction of NBT (nitroblue tetrazolium), following Cakmak (1994). One unit of SOD was defined as the amount of enzyme necessary to cause $50 \%$ inhibition of the rate of NBT reduction at $560 \mathrm{~nm}$. The activity of CAT was determined according to Bergmeyer \& Grabl (1983), the decomposition of $\mathrm{H}_{2} \mathrm{O}_{2}$ was measured by the decline in absorbance at $240 \mathrm{~nm}$. APX was assayed by recording the decrease in absorbance at $290 \mathrm{~nm}$ due to the decrease in ascorbic acid content (Nakano \& Asada 1981). APX and CAT were expressed per $\mathrm{mg}$ protein, 
and one unit represented $1 \mu \mathrm{mol}$ of substrate undergoing reaction per $\mathrm{mg}$ protein per min.

\section{Statistical analysis}

Analysis of variance (ANOVA) was applied for analyzing the differences in the chemical composition of Anatolian black pine needles between five tree age classes using the SPSS program ver. 11.0 for Windows. Following the results of ANOVAs, Tukey's honestly significance difference (HSD) test $(\alpha=0.05)$ was used for testing differences between group means.

\section{Results}

Variation in photosynthetic pigments

Mean concentrations of photosynthetic pigments (chlorophyll- $a$, $-b$, total chlorophyll and carotenoids) in needle samples of different age classes are shown in Tab. 2. Concentrations varied significantly among age classes $(p<0.001)$. In general, photo- synthetic pigments showed a decrease with tree age, being higher in young (25and 50-year-old) than in old (100-, 200- and over 500-year-old) Anatolian black pine trees (Tab. 2). Mean chlorophyll-a concentration was the highest in 50-year-old trees (0.159 $\left.\mathrm{mg} \mathrm{g} \mathrm{g}^{-1}\right)$, followed by 25-year-old $\left(0.146 \mathrm{mg} \mathrm{g}^{-1}\right), 100$-year-old $\left(0.139 \mathrm{mg} \mathrm{g}^{-1}\right)$, 200-year-old $\left(0.127 \mathrm{mg} \mathrm{g}^{-1}\right)$ and over 500year-old trees $\left(0.124 \mathrm{mg} \mathrm{g}^{-1}\right)$. Mean chlorophyll-b concentration was also the highest in 50-year-old trees, followed by 25-, 200-, over 500-year-old trees, but the lowest concentration was found in 100-year-old trees (Tab. 2). Mean total carotenoid concentration was similar for 25-, 50- and 200year-old trees (approximately $11.00 \mathrm{mg} \mathrm{g}^{-1}$ ) but higher than for 100- and over 500-yearold trees, which had a similar concentration (approximately $7.55 \mathrm{mg} \mathrm{g}^{-1}$ ). Chlorophyll $a / b$ ratio was the highest in 100-yearold trees (4.89), followed by 200- (4.05), over 500- (3.88), 25-(3.19), and 50-year-old trees (2.84).
Variation in proline, total soluble protein, MDA and $\mathrm{H}_{2} \mathrm{O}_{2}$

Mean concentrations of proline, total soluble protein, MDA-malondialdehyde and $\mathrm{H}_{2} \mathrm{O}_{2}$ in Anatolian black pine needles are given in Tab. 3. They all varied significantly among age classes $(p<0.001)$. Mean proline, total soluble protein and $\mathrm{H}_{2} \mathrm{O}_{2}$ concentrations were the highest in over 500-yearold trees $\left(73.46 \mathrm{mg} \mathrm{g}^{-1}, 28.34 \mathrm{mg} \mathrm{g}^{-1}\right.$ and $150.2 \mu \mathrm{mol}$, respectively), whereas mean proline and $\mathrm{H}_{2} \mathrm{O}_{2}$ concentrations were the lowest in 200-year-old trees $(51.61 \mu \mathrm{mol}$ and $100.47 \mu \mathrm{mol}$ ) and mean total soluble protein was the lowest in 25-year-old trees (11.44 $\mathrm{mg} \mathrm{g}^{-1}$ - Tab. 3). Mean MDA-malondialdehyde concentration was also the lowest in 25 -year-old trees $(25.97 \mu \mathrm{mol})$ but the highest in 50-year-old trees (44.05 $\mu \mathrm{mol})$.

Variation in glucose, sucrose and total soluble carbohydrates

Mean concentrations of glucose, sucrose

Tab. 2 - Mean concentrations of chlorophyll $a$, chlorophyll $b$, total chlorophyll and total carotenoids, and ratio of chlorophyll $a / b$ in Anatolian black pine needles of different ages. Different letters in rows indicate significant differences between means ( $p<0.001)$ after Tukey's HSD test.

\begin{tabular}{|c|c|c|c|c|c|c|c|}
\hline \multirow{2}{*}{ Component } & \multicolumn{5}{|c|}{ Mean Tree Age (years) } & \multirow{2}{*}{$\mathbf{F}$} & \multirow{2}{*}{ Prob } \\
\hline & $>500$ & 200 & 100 & 50 & 25 & & \\
\hline $\begin{array}{l}\text { Chlorophyll } a \\
\left(\mathrm{mg} \mathrm{g}^{-1}\right)\end{array}$ & $0.124 \pm 0.001^{a}$ & $0.127 \pm 0.001^{a}$ & $0.139 \pm 0.001^{b}$ & $0.159 \pm 0.001^{d}$ & $0.146 \pm 0.002^{c}$ & 344.1 & $<0.001$ \\
\hline $\begin{array}{l}\text { Chlorophyll } b \\
\left(\mathrm{mg} \mathrm{g}^{-1}\right)\end{array}$ & $0.0319 \pm 0.0003^{b}$ & $0.0314 \pm 0.0008^{b}$ & $0.0283 \pm 0.0006^{a}$ & $0.0560 \pm 0.0004^{d}$ & $0.0458 \pm 0.0004^{c}$ & 541.1 & $<0.001$ \\
\hline $\begin{array}{l}\text { Total Chlorophyll } \\
\left(\mathrm{mg} \mathrm{g}^{-1}\right)\end{array}$ & $0.156 \pm 0.001^{a}$ & $0.159 \pm 0.001^{a}$ & $0.167 \pm 0.001^{b}$ & $0.215 \pm 0.001^{d}$ & $0.192 \pm 0.002^{c}$ & 647.36 & $<0.001$ \\
\hline $\begin{array}{l}\text { Total Carotenoid } \\
\left(\mathrm{mg} \mathrm{g}^{-1}\right)\end{array}$ & $7.56 \pm 0.06^{a}$ & $10.91 \pm 0.07^{b}$ & $7.62 \pm 0.02^{a}$ & $11.02 \pm 0.13^{b}$ & $11.15 \pm 0.10^{b}$ & 510.87 & $<0.001$ \\
\hline $\begin{array}{l}\text { Chlorophyll } a / b \\
\text { ratio }\end{array}$ & $3.88 \pm 0.04^{c}$ & $4.05 \pm 0.11^{c}$ & $4.89 \pm 0.09^{d}$ & $2.84 \pm 0.02^{a}$ & $3.19 \pm 0.04^{b}$ & 149.78 & $<0.001$ \\
\hline
\end{tabular}

Tab. 3 - Mean concentrations of proline, total soluble protein, malondialdehyde (MDA) and hydrogen peroxide $\left(\mathrm{H}_{2} \mathrm{O}_{2}\right)$ in Anatolian black pine needles of different ages. Different letters in rows indicate significant differences between means $(p<0.001)$ after Tukey's HSD test.

\begin{tabular}{|c|c|c|c|c|c|c|c|}
\hline \multirow{2}{*}{ Component } & \multicolumn{5}{|c|}{ Mean Tree Age (years) } & \multirow{2}{*}{$F$} & \multirow{2}{*}{ Prob. } \\
\hline & $>500$ & 200 & 100 & 50 & 25 & & \\
\hline $\begin{array}{l}\text { Proline } \\
\qquad\left(\mathrm{mg} \mathrm{g}^{-1}\right)\end{array}$ & $73.46 \pm 0.16^{d}$ & $51.61 \pm 0.19^{a}$ & $66.70 \pm 0.04^{c}$ & $67.58 \pm 0.08^{c}$ & $60.68 \pm 0.09^{b}$ & 4637.91 & $<0.001$ \\
\hline $\begin{array}{l}\text { Total Soluble Protein } \\
\left(\mathrm{mg} \mathrm{g}^{-1}\right)\end{array}$ & $28.34 \pm 0.24^{\mathrm{e}}$ & $17.61 \pm 0.19^{c}$ & $16.51 \pm 0.22^{b}$ & $19.57 \pm 0.16^{d}$ & $11.44 \pm 0.10^{a}$ & 1101.98 & $<0.001$ \\
\hline $\begin{array}{l}\text { MDA } \\
\quad\left(\mu \mathrm{mol} \mathrm{g} g^{-1}\right)\end{array}$ & $34.82 \pm 0.02^{c}$ & $29.32 \pm 0.02^{b}$ & $39.95 \pm 0.03^{d}$ & $44.05 \pm 0.02^{e}$ & $25.97 \pm 0.01^{a}$ & 173879.86 & $<0.001$ \\
\hline $\begin{array}{l}\mathrm{H}_{2} \mathrm{O}_{2} \\
\quad\left(\mu \mathrm{mol} \mathrm{g}{ }^{-1}\right)\end{array}$ & $150.20 \pm 0.05^{\mathrm{e}}$ & $100.47 \pm 0.24^{\mathrm{a}}$ & $139.21 \pm 0.14^{c}$ & $140.32 \pm 0.07^{d}$ & $123.40 \pm 0.08^{b}$ & 21664.53 & $<0.001$ \\
\hline
\end{tabular}

Tab. 4 - Concentrations of glucose, sucrose and total soluble carbohydrate in Black pine needles of different ages. Different letters in rows indicate significant differences between means $(p<0.001)$ after Tukey's HSD test.

\begin{tabular}{|c|c|c|c|c|c|c|c|}
\hline \multirow{2}{*}{ Component } & \multicolumn{5}{|c|}{ Mean Tree Age (years) } & \multirow{2}{*}{$\mathbf{F}$} & \multirow{2}{*}{ Prob. } \\
\hline & $>500$ & 200 & 100 & 50 & 25 & & \\
\hline $\begin{array}{l}\text { Glucose } \\
\left(\mathrm{mg} \mathrm{g}^{-1}\right)\end{array}$ & $32.30 \pm 0.02^{a}$ & $47.32 \pm 0.02^{\mathrm{e}}$ & $42.44 \pm 0.03^{b}$ & $45.31 \pm 0.03^{d}$ & $45.12 \pm 0.03^{c}$ & 57926.4 & $<0.001$ \\
\hline $\begin{array}{l}\text { Sucrose } \\
\qquad\left(\mathrm{mg} \mathrm{g}^{-1}\right)\end{array}$ & $106.83 \pm 0.07^{e}$ & $102.86 \pm 0.03^{d}$ & $104.28 \pm 0.12^{c}$ & $100.34 \pm 0.07^{b}$ & $97.43 \pm 0.05^{a}$ & 2658.83 & $<0.001$ \\
\hline $\begin{array}{l}\text { Total Soluble } \\
\text { Carbohydrate }\left(\mathrm{mg} \mathrm{g}^{-1}\right)\end{array}$ & $22.94 \pm 0.01^{\mathrm{e}}$ & $22.45 \pm 0.02^{a}$ & $22.80 \pm 0.01^{d}$ & $22.56 \pm 0.01^{b}$ & $22.68 \pm 0.01^{c}$ & 442.32 & $<0.001$ \\
\hline
\end{tabular}


Tab. 5 - Concentrations of ascorbate peroxidase (APX), catalase (CAT) and superoxide dismutase (SOD) in Black pine needles of different ages. Different letters in rows indicate significant differences between means $(p<0.001)$ after Tukey's HSD test.

\begin{tabular}{|c|c|c|c|c|c|c|c|}
\hline \multirow{2}{*}{ Component } & \multicolumn{5}{|c|}{ Mean Tree Age (years) } & \multirow{2}{*}{$F$} & \multirow{2}{*}{ Prob. } \\
\hline & $>500$ & 200 & 100 & 50 & 25 & & \\
\hline $\begin{array}{l}\text { APX } \\
\text { (EU mg-1 Protein) }\end{array}$ & $0.315 \pm 0.003^{d}$ & $0.213 \pm 0.003^{b}$ & $0.239 \pm 0.002^{c}$ & $0.241 \pm 0.002^{c}$ & $0.205 \pm 0.002^{a}$ & 411.87 & $<0.001$ \\
\hline $\begin{array}{l}\text { CAT } \\
\text { (EU } \mathrm{mg}^{-1} \text { Protein) }\end{array}$ & $0.521 \pm 0.001^{\mathrm{e}}$ & $0.505 \pm 0.002^{d}$ & $0.430 \pm 0.001^{c}$ & $0.242 \pm 0.121^{a}$ & $0.310 \pm 0.001^{b}$ & 5.14 & $<0.001$ \\
\hline
\end{tabular}

and total soluble carbohydrates in Anatolian black pine needles are given in Tab. 4. They all varied significantly among age classes $(p<0.001)$. Needles of over 500year-old trees had the highest mean sucrose $\left(106.8 \mathrm{mg} \mathrm{g}^{-1}\right)$ and total soluble carbohydrate concentrations $\left(22.94 \mathrm{mg} \mathrm{g}^{-1}\right)$, whereas the lowest mean glucose $(32.3 \mathrm{mg}$ $\left.\mathrm{g}^{-1}\right)$. Needles of 200-year-old trees, however, had the highest mean glucose concentration (47.3 $\mathrm{mg} \mathrm{g}^{-1}$ ), and the lowest mean total soluble carbohydrate concentrations (22.45 $\mathrm{mg} \mathrm{g}^{-1}$ ). Needles of 25-year old trees had the lowest mean sucrose concentration (97.4 $\mathrm{mg} \mathrm{g}^{-1}$ - Tab. 4).

Variation in antioxidant enzyme activity Mean concentrations of APX, CAT and SOD in Anatolian black pine needles are given in Tab. 5. They all varied significantly between age classes $(p<0.001)$. Needles of over 500-year-old trees had the highest mean APX (0.315 EU) and SOD (24.6 EU) concentrations, whereas those of 25-yearold trees the lowest (0.205 EU and 11.3 EU). Needles of over 500-year-old trees had the highest CAT concentration ( $0.521 \mathrm{EU})$, the lowest being found for 50-year-old trees (0.242 EU - Tab. 5).

\section{Discussion}

\section{Effects of tree age on photosynthetic \\ pigment concentration}

The photosynthetic pigments play a role in capturing sunlight and converting it into chemical energy (Ito et al. 1994, Mirkovic et al. 2017). In this study, chlorophyll $a$, chlorophyll $b$ and total chlorophyll concentrations were generally lower in older Anatolian black pine trees (over 500-, 200- and 100-year-old trees) compared to younger trees (50- and 25-year-old trees - Tab. 2). Chlorophyll $a / b$ ratio was, however, higher in the needle samples from 100- and 200year-old trees, as compared with younger trees (Tab. 2). Lower total carotenoid concentration was found in the needles from over 500- and 100-year-old trees, in comparison with 25- and 50-year-old trees (Tab. 2). We hypothesize that the variation in tree canopy height with age could determine such differences. Although we did not measure light conditions in the study area, 100-year-old trees were growing in rather open canopy conditions, in comparison with 50- and 25-year-old trees, while 200- and over 500-year-old trees were growing in intermediate conditions. Similar results were also reported by Ito et al. (1994) and Ohtsuka et al. (1997), who showed that chlorophyll $b$ increased under low light conditions, whereas the amount of chlorophyll $a$ and the ratio chlorophyll $a / b$ decreased. The average value of chlorophyll $a / b$ ratio in 200-year-old trees was thought to be due to low concentrations of MDA-malondialdehyde and $\mathrm{H}_{2} \mathrm{O}_{2}$. The reason for the presence of highest amount of chlorophyll $a$ in this tree age group could be related to adaptation mechanisms for ensuring photoassimilate source/pool ratio. High chlorophyll amounts were found linked with photosynthetic electron transfer, thereby contributing to an increase in the synthesis of ATP, NADPH+ and photoassimilate products (Mirkovic et al. 2017). Low chlorophyll $a / b$ ratios in 25 - and $50-$ year-old trees were probably associated with low light conditions.

\section{Effects of tree age on proline, total soluble protein, MDA and $\mathrm{H}_{2} \mathrm{O}_{2}$}

\section{concentrations}

Proline and total soluble protein contents were lower in younger Anatolian black pine trees. Protein concentration was the lowest in 25-year-old trees, whereas the highest in over 500-year-old trees (Tab. 3). Nitrogen compounds are utilized as nitrogen, carbon and energy source in growth and development (Paungfoo-Lonhienne et al. 2008). Proline and soluble proteins are involved in cell wall relaxation, turgor and osmotic potential (Heuer 1999), activities that can be affected by tree size/age. Concentrations of $\mathrm{H}_{2} \mathrm{O}_{2}$, proteins, and carbohydrates in older Anatolian black pine tree support this hypothesis. Proline concentration for 100-year-old trees was probably associated with high irradiance. Nitrogenous compounds in 50- and 25-year-old trees were related to low source/pool photoassimilate ratio, these trees being in the juvenile phase.

Cellular components, which undergo the first change during the cell cycle, are plasma and organelle membranes, and cell walls (Spiteller 2003). The concentration of MDA-malondialdehyde was affected by tissue differentiations in younger trees, while MDA-malondialdehyde was affected by tissue deformation in older trees (Renaud \& Mauffette 1991). Changes in structural cellular membrane were found to affect MDAmalondialdehyde amounts during tissue ontogenesis and stimulate accumulation of $\mathrm{H}_{2} \mathrm{O}_{2}$ (Ros Barceló 1998, Spiteller 2003).
$\mathrm{H}_{2} \mathrm{O}_{2}$ concentration was higher for over 500-, 50- and 100-year-old trees than for 200- and 25-year-old trees (Tab. 3). $\mathrm{H}_{2} \mathrm{O}_{2}$ concentration varied according to tissue deformation in older trees and tissue differentiation in young trees (Ros Barceló 1998). The lowest level of $\mathrm{H}_{2} \mathrm{O}_{2}$ for 200year-old trees could be attributed to their transitional growth phase. The concentration of $\mathrm{H}_{2} \mathrm{O}_{2}$ in 50- and 100-year-old trees was associated with tree growth and increased branching. $\mathrm{H}_{2} \mathrm{O}_{2}$ concentration in 25 -year-old trees was linked with the juvenile phase.

\section{Effects of tree age on glucose, sucrose and total soluble carbohydrates}

\section{concentrations}

Assimilates, such as glucose, fructose and sucrose, are directly metabolized and used as a carbon and energy source (Peichl \& Arain 2006). Glucose concentration was the highest in 200-year-old trees, while sucrose and total soluble carbohydrate concentrations were maximum in over 500year-old trees. In contrast, glucose was the lowest in over 500-year-old trees, and sucrose and total soluble carbohydrate concentrations were minimum in 25-year-old trees (Tab. 4). Glucose concentration varied according to metabolic needs and size of Anatolian black pine trees. Tree height and sucrose concentration in older plants have been related to hydraulic conductivity (Ritchie \& Keeley 1994, Koch et al. 2004). Low glucose and high proline, protein, sucrose and total soluble sugar contents in over 500-year-old trees suggest that glucose was metabolized to sucrose and used for increasing osmotic potential. Chlorophyll $a / b$, total soluble carbohydrate and glucose contents in 50- and 25-year-old trees were probably associated to low-light conditions (Valladares \& Niinemets 2008).

\section{Effects of tree age on antioxidant enzyme activity}

Antioxidant enzymes protect the structure of membranes, proteins, enzymes and other molecules from ROS derivative damage (Cakmak 1994, Teeri \& Simola 2002). Morphological and physiological changes in plant organs/tissues affect antioxidant activities (Ray et al. 2012). APX was maximum in over 500- and 50-year-old trees, while CAT and SOD activities were maximum in over 500- and 200-year-old trees. The highest enzyme activity found in these trees could be associated with catabolic re- 
actions for tissue deformation and senescence. It has been reported that leaf area becomes smaller in aging coniferous trees, while lignin content increases (Teeri \& Simola 2002). In 100-year-old trees, the low carotenoid and protein content, and high MDA-malondialdehyde and $\mathrm{H}_{2} \mathrm{O}_{2}$, might affect enzyme activity. Lignin deposition might also affect enzyme activity in 50year-old trees (Rossi et al. 2008). The lowest enzyme activity noted in 25-year old trees could be related to their juvenile phase (Niinemets 2002).

\section{Conclusions}

Our results showed that under similar environmental conditions, the chemical compounds synthesized in Anatolian black pine needles are significantly influenced by tree age. In general, photosynthetic pigments (chlorophyll $a$, chlorophyll $b$, total chlorophyll and carotenoid concentrations) and glucose concentrations in the needles from 25-year-old trees were higher than those for needles from the over 500-year-old trees, whereas proline, total soluble protein, MDA-malondialdehyde, $\mathrm{H}_{2} \mathrm{O}_{2}$, sucrose, and antioxidant (APX, CAT, SOD) concentrations were significantly higher in needles from over 500-year-old trees. All those chemical compounds in plant needles are related to plant defence against attacks by herbivores and litter decomposition. A more detailed understanding of primary and secondary metabolism in Anatolian black pines and variation in primary and secondary metabolites within and among plants and with time are required, and such analyses will be useful for complementing studies on tree growth-defence relationships.

\section{Acknowledgements}

This research has been supported by the Kastamonu University Scientific Research Projects Coordination Department, project no. KUBAP-01-2013-17 and no. KUBAP-012014-21.

\section{References}

Arnon DI (1949). Copper enzymes in isolated chloroplasts. Polyphenol oxidase in Beta vulgaris. Plant Physiology 24: 1-15. - doi: 10.1104/pp. 24.1.1

Atalay I, Efe R (2012). Ecological attributes and distribution of Anatolian black pine (Pinus nigra Arnold. subsp. pallasiana Lamb. Holmboe) in Turkey. Journal of Environmental Biology 33: 509-519.

Bates LS, Waldern RP, Teare ID (1973). Rapid determination of free proline for water-stress studies. Plant and Soil 39: 205-207. - doi: 10.1007 /BFoo018060

Bergmeyer J, Grabl M (1983). Methoden der enzymatischen analyse [Methods of enzymatic analysis]. Akademie Verlag 1: 190-302. [in German]

Bond BJ, Czarnomski NM, Cooper C, Day ME, Michael SG (2007). Development decline in height growth in Douglas-fir. Tree Physiology
27: 441-453. - doi: 10.1093/treephys/27.3.441 Bradford M (1976). A rapid and sensitive method for the quantitation of microgram quantities of protein utilizing the principle of protein-dye binding. Analytical Biochemistry 72 (1-2): 248254. - doi: 10.1016/0003-2697(76)90527-3

Cakmak I (1994). Activity of ascorbate-dependent $\mathrm{H}_{2} \mathrm{O}_{2}$-scavenging enzymes and leaf chlorosis are enhanced in magnesium and potassium deficient leaves, but not in phosphorus deficient leaves. Journal of Experimental Botany 45: 1259-1266. - doi: 10.1093/jxb/45.9.1259

Duran C (2017). Local distribution of the temperature and precipitation in Kastamonu province and surrounding. The Journal of International Social Research 10 (52): 509-516. - doi: 10.17719/ jisr.2017.1911

Gower ST, McMurtrie RE, Murty D (1996). Aboveground net primary production decline with stand age: potential causes. Trends in Ecology and Evolution 11: 378-382. - doi: 10.1016/ 0169-5347(96)10042-2

Greenwood MS, Day ME, Schatz J (2010). Separating the effects of tree size and meristem maturation on shoot development of grafted scions of red spruce (Picea rubens Sarg.). Tree Physiology 30: 459-468. - doi: 10.1093/treephys/ tpqoo4

Heuer B (1999). Osmoregulatory role of proline in plants exposed to environmental stressed. In: "Handbook of Plant and Crop Stress"(Pessarakli $M$ ed). Marcel Dekker, New York, USA, pp. 675-695.

Ito H, Takaichi S, Tsuji H, Tanaka A (1994). Properties of synthesis of chlorophyll a from chlorophyll b in cucumber etioplasts. Journal of Biological Chemistry 269: 22034-22038. [online] URL: http://www.jbc.org/content/269/35/2203 4.short

Koch GW, Sillett SC, Jennings GM, Davis SD (2004). The limits of tree height. Nature 428: 851-854. - doi: 10.1038/nature02417

Köstner B, Falge E, Tenhunen JD (2002). Agerelated effects on leaf area/sapwood area relationships, canopy transpiration and carbon gain of Norway spruce stands (Picea abies) in the Fichtelgebirge, Germany. Tree Physiology 22: 567-574. - doi: 10.1093/treephys/22.8.567

Lutts S, Kinet JM, Bouharmont J (1996). NaClinduced senescence in leaves of rice (Oryza sativa L.) cultivars differing in salinity resistance. Annals of Botany 78: 389-398. - doi: 10.1006/anbo.1996.0134

Mirkovic T, Ostroumov EE, Anna JM, Van Grondelle R, Govindjee Van G, Scholes GD (2017). Light absorption and energy transfer in the antenna complexes of photosynthetic organisms. Chemical Reviews 117: 249-29. - doi: 10.1021/acs. chemrev.6boooo2

Nakano Y, Asada K (1981). Hydrogen peroxide is scavenged by ascorbate-specific peroxidase in spinach chloroplasts. Plant Cell Physiology 22 (5): 867-880. - doi: 10.1093/oxfordjournals.pcp. a076232

Niinemets $U$ (2002). Stomatal conductance alone does not explain the decline in foliar photosynthetic rates with increasing tree age and size in Picea abies and Pinus sylvestris. Tree Physiology 22: 515-535. - doi: 10.1093/treephys/ 22.8.515
Ohtsuka T, Ito H, Tanaka A (1997). Conversion of chlorophyll $\mathrm{b}$ to chlorophyll $\mathrm{a}$ and the assembly of chlorophyll with apoproteins by isolated chloroplasts. Plant Physiology 113: 137-147. - doi: 10.1104/pp.113.1.137

Paungfoo-Lonhienne C, Lonhienne TGA, Rentsch D, Robinson N, Christie M, Webb RI (2008). Plants can use protein as nitrogen source without assistance from other organisms. Proceedings of the National Academy of Sciences USA 105: 4524-9. - doi: 10.1073/pnas.0712078105

Pearson D, Melon HK, Ronald S (1976). Chemical analysis of food (8th edn). Churchill Livingstone, London and New York, pp. 5-63.

Peichl M, Arain MA (2006). Above and below ground ecosystem biomass and carbon pools in an age-sequence of temperate pine plantation forests. Agricultural and Forest Meteorology 140: 51-63. - doi: 10.1016/j.agrformet.2006.08. 004

Ray P, Huang BW, Tsuji Y (2012). Reactive oxygen species (ROS) homeostasis and redox regulation in cellular signalling. Cell Signal 24: 981990. - doi: 10.1016/j.cellsig.2012.01.008

Renaud JP, Mauffette Y (1991). The relationships of crown dieback with carbohydrate content and growth of sugar maple (Acer saccharum). Canadian Journal of Forest Research 21: 11111118. - doi: 10.1139/x91-153

Ritchie GA, Keeley JW (1994). Maturation in Douglas-fir: I. Changes in stem, branch and foliage characteristics associated with ontogenetic aging. Tree Physiology 14: 1245-1259. - doi: 10.10 93/treephys/14.11.1245

Ros Barceló A (1998). Hydrogen peroxide production is a general property of the lignifying xylem from vascular plants. Annals of Botany 82: 97-103. - doi: 10.1006/anbo.1998.0655

Rossi S, Deslauriers A, Anfodillo T, Carrer M (2008). Age-dependent xylogenesis in timberline conifers. New Phytologist 177: 199-208. doi: 10.1111/j.1469-8137.2007.02235.x

Sariyildiz T, Anderson JM (2006). Intra-specific variation in cell wall constituents of needle age classes of Pinus sylvestris in relation to soil fertility status in Southwest England. Silva Fennica 40 (1): 15-26. - doi: 10.14214/sf.349

Spiteller G (2003). The relationship between cell wall, lipid peroxidation, proliferation, senescence and cell death. Physiologia Plantarum 119: 5-18. - doi: 10.1034/j.1399-3054.2003.0009 7.x

Teeri TH, Simola LK (2002). Lignification related enzymes in Picea abies suspension cultures. Physiologia Plantarum 114: 343-353. - doi: 10.1034/j.1399-3054.2002.1140303.x

Valladares F, Niinemets U (2008). Shade tolerance, a key plant feature of complex nature and consequences. Annual Review of Ecology, Evolution, and Systematics 39: 237-257. - doi: 10.1146/annurev.ecolsys.39.110707.173506 Velikova V, Yordanov I, Edreva A (2000). Oxidative stress and some antioxidant systems in acid rain-treated bean plants: protective roles of exogenous polyamines. Plant Science 151: 59-66. - doi: 10.1016/S0168-9452(99)00197-1 Witham FH, Blaydes DF, Devli RM (1971). Experiments in plant physiology. Van Nostrand Reinhold Company, New York, USA, pp. 55-56. 